\title{
Estradiol Regulation of Prostanoids Production in Endothelium
}

\author{
Susana Novella and Carlos Hermenegildo \\ Department of Physiology, University of Valencia \\ Research Foundation- INCLIVA, Hospital Clínico UniversitarioValencia \\ Spain
}

\section{Introduction}

The endothelium is a continuous cellular monolayer lining the interior of the blood vessels and heart. Classically considered to exert its actions only as a mechanical barrier, also plays important roles in vascular physiology. Endothelium participates in numerous metabolic and regulatory functions such as the control of primary hemostasis, blood coagulation and fibrinolysis, interaction with lipoprotein metabolism, platelet and leukocyte interactions with the vessel wall, presentation of histocompatibility antigens, regulation of vascular tone and growth, and of blood pressure. The endothelium exerts these actions through the release of such vasoactive compounds as prostacyclin, thromboxane $\mathrm{A}_{2}$, nitric oxide (NO), bradykinin, endothelin, angiotensin, and free radicals that control the functions of vascular smooth muscle cells and of circulating blood cells (Ross, 1999; Vapaatalo \& Mervaala, 2001).

The integrity and functionality of the arterial endothelium play a crucial role in the physiology of circulation (Filipe et al., 2008) and, as a consequence, in preventing the development of cardiovascular diseases, whose genesis is currently considered a consequence of the anatomical and functional disruption of the endothelium (Spyridopoulos et al., 1997). When the ability of the endothelial cells to release relaxing is reduced, and in particular if the propensity to produce contractile factors is enhanced, endothelial dysfunction appears as a first step in the sequence of events that leads to atherosclerosis and coronary disease. Thus, no single mechanism is responsible for all endothelium dependent responses and their modulation by pathophysiological states leads to endothelial dysfunction characterized by an imbalance in endothelial regulators (Vanhoutte et al., 2009).

Clinical and experimental data support the consideration of endothelium as a target for estradiol and other sexual hormones. A number of studies have demonstrated a favourable profile for estrogens in both experimental animal, as well as in in vitro models (Turgeon et al., 2006). However, the protective effect detected in a considerable number of observational clinical studies (Barrett-Connor \& Grady, 1998) has not been confirmed by randomized placebo-controlled trials (Hulley et al., 1998; Grady et al., 2002), which described clinical complications, such as thrombosis in veins and coronary arteries, developed in postmenopausal women during the administration of exogenous hormones (Cano et al., 2007). 
A number of studies have demonstrated that estrogens exert significant benefits on the cardiovascular system, and at least a part of these benefits are attributed to the direct effect of estradiol on vascular endothelial cells (Mendelsohn \& Karas, 1999; Rubanyi et al., 2002; Sader \& Celermajer, 2002). Estradiol is able to stimulate endothelial NO production through several mechanisms, including increased expression of NO synthases (mainly endothelial NO synthase), increased L-arginine availability, non-genomic activation of second messengers (Simoncini, 2009), translocation to intracellular sites, modulation of NO degrading sites (Tostes et al., 2003), and modulation of endogenous antagonist levels (Monsalve et al., 2007).

Additionally, estradiol is able to exert antioxidant actions on endothelium (Shwaery et al., 1998; Hermenegildo et al., 2002), to modulate the renin-angiotensin system (Farhat et al., 1996; Alvarez et al., 2002), and to decrease endothelin-1 production (Mikkola et al., 1995; Akishita et al., 1998). Furthermore, estradiol regulates endothelial cell expression of adhesion molecules (Caulin-Glaser et al., 1996; Abu-Taha et al., 2009).

Estradiol has also been implicated on the regulation of prostanoids production in endothelial cells. Two main vascular prostanoids, prostacyclin and thromboxane $\mathrm{A}_{2}$, play an essential role in the maintenance of vascular homeostasis. Prostacyclin is a vasodilator and an inhibitor of platelet aggregation; in contrast, thromboxane $A_{2}$ is a vasoconstrictor and a promoter of platelet aggregation. As a consequence of their opposing roles, an imbalance in prostacyclin or thromboxane production has been implicated in the physiopathology of many thrombotic and cardiovascular disorders. In this chapter, we will discuss clinical and experimental data that document the endothelial effects of estradiol on prostanoid production and regulation, and their vascular consequences.

\section{Prostanoids in endothelium}

Prostanoids are unstable lipid mediators that, after intracellular biosynthesis, are released outside the endothelial cell. It is believed that prostanoids work mostly locally in an autocrine or paracrine way. Prostanoids are ubiquitous compounds that coordinate a wide variety of physiological and pathological processes via membrane receptors on the surface of target cells (FitzGerald, 2002). Prostanoids include prostaglandins (such as prostaglandins $\mathrm{D}_{2}, \mathrm{E}_{2}, \mathrm{~F}_{2}, \mathrm{~F}_{2 \mathrm{a}}, \mathrm{PGI}_{2}$-or prostacyclin-) and thromboxanes (such as $\mathrm{TXA}_{2}$ ) (Smith et al., 2000; Linton \& Fazio, 2002).

Prostanoids production is mainly regulated by the availability of free arachidonic acid and the activity of cyclooxygenases (COX). Release of arachidonate from cell membrane phospholipids is mediated through phospholipases, mainly phospholipase $A_{2}$. Once arachidonate is released, it is sequentially converted to prostaglandins $\mathrm{G}_{2}$ and $\mathrm{H}_{2}$ by two COX isoenzymes (COX-1 and COX-2). The unstable prostaglandin $\mathrm{H}_{2}$ is then transformed into biologically active prostanoids by specific synthases in different cells. Prostaglandins interact with G-protein-coupled receptors, classified in function of their preferential affinity towards the five primary prostaglandins (Tsuboi et al., 2002) (Figure 1).

COX isoenzymes (also known as prostaglandin endoperoxide synthases or prostaglandin $\mathrm{H}$ synthases) are the rate-limiting step in the formation of prostanoids from arachidonic acid and represent the main control mechanism for prostaglandin production (Smith et al., 2000). Both enzymes have similar biochemical activity in converting arachidonic acid to $\mathrm{PGH}_{2}$ in tissue or in recombinant enzyme systems (Vane et al., 1998).

COX-1 and COX-2 are encoded by two different genes derived from human chromosomes 9 and 1 , respectively. In spite of there is a $60-65 \%$ homology between the isoforms within 
species, the activity and the pattern of gene expression of these enzymes are differentially regulated (Davidge, 2001).

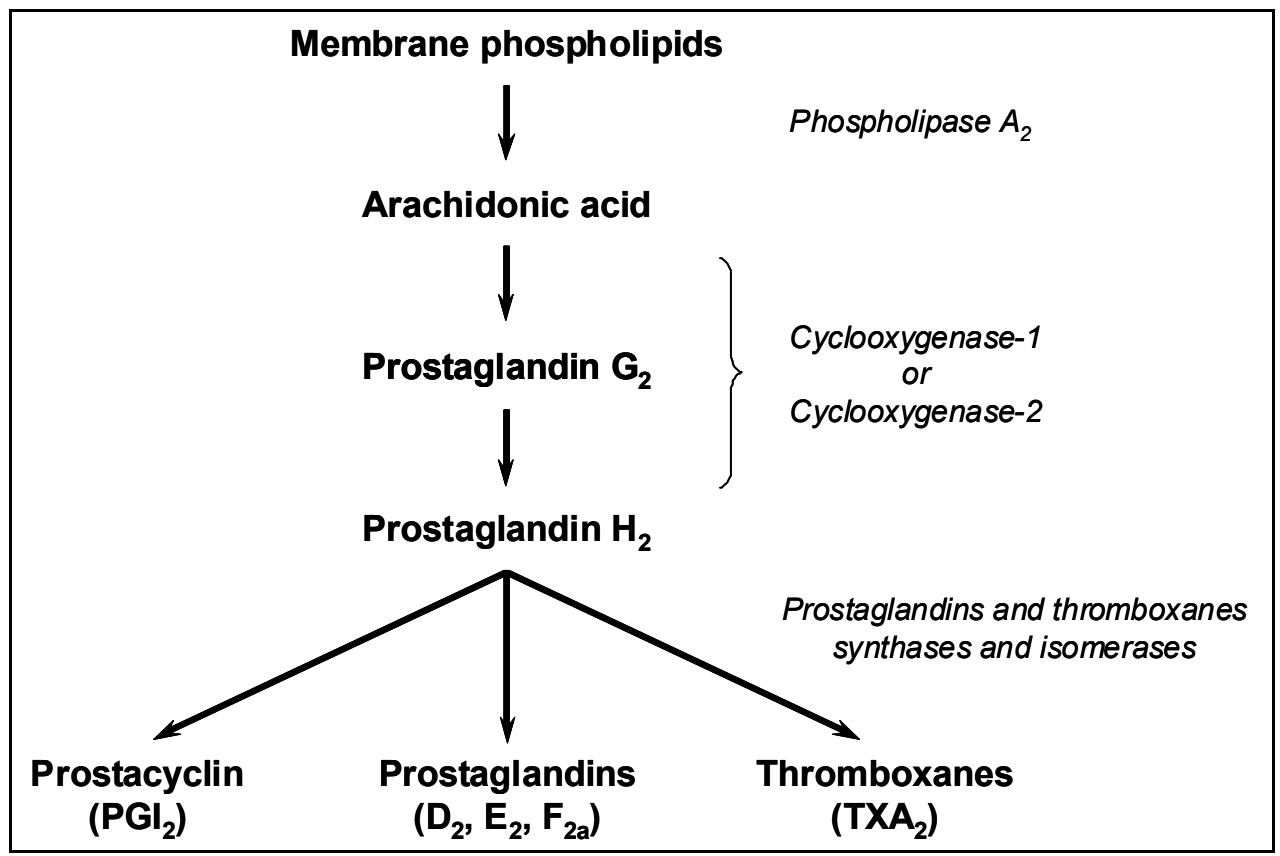

Fig. 1. Biosynthesis of prostaglandins and thromboxanes.

COX-1 has been considered to be the constitutively expressed protein, while COX-2 is induced at sites of inflammation. Following that hypothesis, COX-1 would generate prostaglandins for physiological, housekeeping functions like gastrointestinal mucosal integrity and regulation of renal blood flow, while COX-2 would form the prostaglandins responsible for inflammatory symptoms (Smith et al., 2000; Parente \& Perretti, 2003).

But this separation of functions is so not clear. For instance, COX-2 is constitutively expressed in some regions of the central nervous system, and in renal and uterus tissues, suggesting it may play a role under physiologic conditions (Kim et al., 1999; FitzGerald, 2002; Cheng \& Harris, 2004). In fact, both COX-1 and COX-2 are involved not only in physiological, but also in pathological processes. The importance of this topic has impelled many outstanding reviews (Vane et al., 1998; Parente \& Perretti, 2003; Cipollone et al., 2008; Vanhoutte, 2009).

Regarding the vascular system, both isoenzymes are expressed in endothelium and smooth muscle cells. However, endothelial cells contain up to 20 times more COX than smooth muscle cells (DeWitt et al., 1983). As mentioned before for other organs, COX-1 has usually been considered in endothelium as the constitutive isoform, while COX-2 is induced by a number of cardiovascular risk factors, such as cytokines, cholesterol, lipoproteins, and hypoxia. Actually, both COX isoenzymes share characteristics of constitutive and inducible enzymes in endothelium. Shear stress induces COX-1 gene expression in human umbilical vein endothelial cells (HUVEC) (Doroudi et al., 2000), while clinical studies with a selective 
inhibitor of COX-2 (celecoxib) have shown that this enzyme exerts control of most systemic prostacyclin production in healthy humans (McAdam et al., 1999).

Although prostaglandins $E_{2}$ and $F_{2 \alpha}$ can contribute to vascular phenotype, two main prostanoids play an essential role in vascular physiology: thromboxane $A_{2}$ and prostacyclin. On the one hand, in the cardiovascular system, thromboxane $A_{2}$ is predominantly derived from platelet COX-1, but can also be produced by other cell types including the endothelial cells. The stimulation of thromboxane receptors elicits not only platelet aggregation and smooth muscle contraction, but also the expression of adhesion molecules and the adhesion and infiltration of monocytes/macrophages (Nakahata, 2008). As platelets are anucleate, there can be no induction of COX-2 enzyme synthesis (Patrignani et al., 1999). Thromboxane $\mathrm{A}_{2}$ can also be synthesized from endothelial cells (Sellers \& Stallone, 2008). The third possibility is a transcellular formation of thromboxane $\mathrm{A}_{2}$ by platelets from prostaglandin $\mathrm{H}_{2}$ released by endothelial cells (Camacho \& Vila, 2000). Thromboxane $A_{2}$ promotes irreversible platelet aggregation, vasoconstriction, and smooth muscle proliferation and, consequently, plays an important role as a mediator of not only haemostasis, but also of acute vascular occlusive events and atherogenesis (FitzGerald, 2002; Weir et al., 2003).

On the other hand, in most blood vessels prostacyclin is the main prostanoid produced by endothelial cells, and the endothelium is its major source (Moncada \& Vane, 1978). Both COX-1 and COX-2 isoenzymes contribute to the production of endothelial prostacyclin. By stimulating its preferential receptor, prostacyclin is a potent inhibitor of platelet adhesion to the endothelial cell surface and of platelet aggregation, and generally acts as an endothelium-derived vasodilator and an inhibitor of vascular smooth muscle migration and proliferation (Moncada \& Vane, 1978; Fetalvero et al., 2007).

Under physiological conditions, endothelial prostacyclin is a counterregulatory influence to platelet-derived thromboxane, and eicosanoids produced by the COX pathways generally induce vasorelaxation. Nevertheless, in some pathologic circumstances, such as oxidative stress and dyslipidemia, there may be an imbalance where COX-dependent vasoconstrictors and platelet aggregation become more predominant. Reactive oxygen species, such as superoxide anion and hydrogen peroxide are derived from multiple sources within inflammatory leukocytes and vascular tissues including NADPH oxidase, uncoupled endothelial and inducible endothelial NO synthase, xanthine oxidase, cyclooxygenases, lipoxygenases, cytochrome P450 monooxygenases and excess substrate utilization by mitochondria. Additionally, NO reacts with superoxide anion to form the extremely potent oxidant, peroxynitrite. Low concentrations of peroxinitrite selectively nitrate and inactivate prostacyclin synthase, which not only eliminates the vasodilatory, growth-inhibiting, antithrombotic, and antiadhesive effects of prostacyclin, but also increases release of the potent vasoconstrictor, prothrombotic, growth- and adhesion-promoting agents, prostaglandin $\mathrm{H}_{2}$ and thromboxane $\mathrm{A}_{2}$ being in general deleterious to vascular function (Zou et al., 2004; Schildknecht \& Ullrich, 2009; Feletou et al., 2010).

\section{Estrogens actions on endothelium}

Estradiol is the most potent estrogen in humans, and exerts its actions mainly through binding and activation of estrogen receptors (ER). Two major subtypes of ER (ERa and ER $\beta$ ) have been identified. These receptors vary not only in their tissue distributions, but also in their agonist/antagonist profile of several compounds (Cano \& Hermenegildo, 2000). Both 
types of ER belong to the class of intracellular receptors classically defined as nuclear ligand-activated transcription factors. Activation of these receptors by the corresponding hormones affects gene expression by acting on specific sequences in the target genes, known as estrogen-response elements, and by modulating transcriptional events.

The contribution of both receptors to the regulation of vascular effects is still under study. There is controversy about whether estrogenic effects are mediated through ERa, ER $\beta$ or both. In the cardiovascular system, ERa and ER $\beta$ have been identified by different techniques in the endothelium, smooth muscle cells and adventitia and on adrenergic nerve endings of arteries from various territories and several species, including humans (Karas et al., 1994; Kim-Schulze et al., 1996; Venkov et al., 1996; Register \& Adams, 1998). Although it has been reported cultured endothelial cells do not express ERa (Toth et al., 2008), other investigators have demonstrated the presence of both ERa and ER $\beta$ mRNA in endothelium (Wagner et al., 2001) and data from our group demonstrate the protein expression of both ERa and ER $\beta$ in HUVEC (Sobrino et al., 2009; Sobrino et al., 2010).

Although the relative significance of both ER subtypes in the vascular actions of estrogens is still under study, data from mice lacking either ERa (Pare et al., 2002; Arnal et al., 2010) or ER $\beta$ (Zhu et al., 2002), and also from a non-functional mutation of ERa in a male patient (Sudhir et al., 1997), reveal an impaired vascular function. Therefore, ERa is probably critical for the production of estrogen vascular protective actions (Favre et al., 2010), but ER $\beta$ may have relevant functions at the vascular level too (Simoncini et al., 2004). The changes in vascular cell gene and protein expression mediated by those ERa and/or ER $\beta$ produce the classic, and better known, longer-term effects of estrogen (Cano \& Hermenegildo, 2000).

ER act in the nucleus as ligand-activated transcription factors that regulate gene expression in response to hormone binding. ER can also regulate vascular cell gene expression in the absence of estrogen following activation by growth factor signalling pathways, a process referred to as ligand-independent transcriptional activation. In addition, ER are able to signal rapidly (from seconds to minutes), in an apparently non-nuclear manner, resulting in downstream activation of specific kinases and their effectors molecules (Mendelsohn \& Karas, 2010).

The rapid effects of estrogens have been also explained by ER-independent mechanisms of action. For instance, the G protein-coupled receptor GPR30 has been proposed to be a third form of ER, although it is controversial whether GPR30 is a biologically-relevant ER or a collaborator in non-nuclear functions of the classical ER in certain contexts (Levin, 2009). Moreover, even though GPR30 is expressed in certain endothelial cells, there is currently a lack of clear evidence of a role for the receptor in estrogen action in endothelium (Wu et al., 2011).

Rapid actions of estradiol include several endothelial pathways, being the activity of endothelial nitric oxide synthase the most studied (Chow et al., 2010). Other signalling pathways acutely activated by estradiol in endothelium are several kinases, such as phosphotidylinositol 3-kinase (PI3K) (Razandi et al., 2000), protein kinase C (PKC) (Akarasereenont et al., 2000) and Rho-associated kinase (ROCK) (Simoncini et al., 2006; Oviedo et al., 2011). Rapid actions are responsible for the acute and potent vasorelaxation induced by estradiol both at physiological (Teoh et al., 2000; Tep-areenan et al., 2003) or supraphysiological (Naderali et al., 2001; Salom et al., 2002) concentrations, and it has been demonstrated in isolated vessels from animals such as rats (Tep-areenan et al., 2003), pigs (Teoh et al., 2000), rabbits (Salom et al., 2002), guinea pigs (Naderali et al., 2001), and even from human beings (Chester et al., 1995). 
In addition, steroid hormone genomic and non-genomic effects may occur simultaneously and may act at different levels, revealing the complexity of estrogen regulation of vascular function (Tostes et al., 2003).

\section{Estrogens actions on prostanoids vascular regulation}

The actions of estrogens on prostanoids vascular production will be presented in two sections: first, those experimental data that are rapid in onset and short in duration (within minutes; "non-genomic" effects); second, those experimental data that are delayed in onset and prolonged in duration (require from hours to days to occur; "genomic" effects).

\subsection{Rapid effects of estrogens on prostanoids vascular production}

Physiological concentrations of estradiol cause a rapid stimulation of prostacyclin synthesis (within $15 \mathrm{~min}$ ) in two types of cultured endothelial cells, ovine fetal pulmonary artery endothelial cells (PAEC) (Sherman et al., 2002) and HUVEC (Alvarez et al., 2002). In both cases, the use of the ER-antagonist ICI182780 reveals that the increased prostacyclin production is mediated through ER activation. In ovine PAEC, it seems mediated through ER $\beta$, since prostacyclin stimulation with estradiol was fully blocked by the ER $\beta$ - antagonist RR-tetrahydrochrysene. Moreover, in ovine PAEC, the increased prostacyclin production is not related to changes in COX-1 or COX-2 protein abundance, thus reinforcing the implication of non-genomic mechanisms (Table 1) (Sherman et al., 2002).

COX-pathway activity is involved in the acute relaxation afforded by estradiol. In rat mesenteric vessels and aorta, COX inhibition with indomethacin enhances the vasodilator potency of estradiol, suggesting an endogenous release of vasoconstrictor prostanoids (Tepareenan et al., 2003). But estradiol also indirectly affects vasoreactivity to contracting and relaxing substances. In epicardial porcine coronary arteries activation of ERa, but not of ER $\beta$, reduces thromboxane $A_{2}$ vasoconstriction, indicating another indirect and vasodilator function of ERa (Traupe et al., 2007). Other data suggest that the estrogen-dependent constrictor prostanoid mechanism in the vascular wall may play an important role in the regulation of vascular tone in the female, in both normal and pathophysiological states. In that way, endogenous estrogen acts as an important regulator of constrictor prostanoid function in female rat aorta, involving the potentiation of COX-2 and thromboxane synthase expression in vascular wall (Li et al., 2008).

Data from studies performed on postmenopausal women also supports the importance of COX-pathway in acute estrogen-induced vasodilation. Estradiol induces a rapid increase of cholinergic cutaneous vasodilation, which is eliminated in women treated for 6 weeks with celecoxib, suggesting that the COX-2 pathway plays a specific role in the rapid estradiolinduced vasodilation in postmenopausal women (Calkin et al., 2002).

Some studies have been performed at times that do not clarify whether the observed effects are genomic or non-genomic actions. Estrogen stimulates rat aortic endothelial cell release of prostacyclin after 1 hour of incubation without affecting COX-1 levels (Myers et al., 1996). That stimulation could be mediated by NO, since endogenous NO increased production of prostacyclin and thromboxane $\mathrm{A}_{2}$ in bovine coronary microvascular endothelial cells within 1 hour, without affecting COX-1 or COX-2 expressions (Davidge et al., 1995). At molecular level, exposure of HUVEC for $40 \mathrm{~min}$ to estradiol significantly increases the expression of roughly 250 genes, measured by DNA microarray analysis. Among them, the COX-2 gene was the strongest up-regulated by estradiol. In fact, estradiol induced COX-2 gene 
expression and new COX-2 protein synthesis by 40 and 60 min, respectively, and quickly stimulated the secretion of prostacyclin and prostaglandin $\mathrm{E}_{2}$ in an ER-dependent manner (Pedram et al., 2002). A similar, significant induction of COX-2 mRNA levels is obtained in human placental villous endothelial cells exposed to estradiol up to 1 hour, without an increased protein production (Su et al., 2009).

\begin{tabular}{lllll}
\hline \hline Cell type & Time & $\begin{array}{l}\mathrm{E}_{2} \\
(\mathrm{nM})\end{array}$ & $\begin{array}{l}\text { Prostacyclin } \\
\text { production }\end{array}$ & COX-1 COX-2 Reference \\
\hline \hline
\end{tabular}

$\underline{\text { Rapid effects }}$

$\begin{array}{rrccccc}\text { Ovine fetal PAEC } & 15 \mathrm{~min} & 10 & \uparrow 52 \% & \leftrightarrow & \leftrightarrow & \text { (Sherman } \text { et al., 2002) } \\ \text { HUVEC } & 15 \mathrm{~min} & 1 & \uparrow 57 \% & \text { NA } & \text { NA } & \text { (Alvarez } \text { et al., 2002) } \\ \text { HUVEC } & 30 \mathrm{~min} & 1 & \uparrow 134 \% & \text { NA } & \text { NA } & \text { (Alvarez } \text { et al., 2002) }\end{array}$

Delayed effects

\begin{tabular}{|c|c|c|c|c|c|c|}
\hline HUVEC & $24 \mathrm{~h}$ & 10 & $\uparrow 26 \%$ & NA & NA & (Mikkola et al., 1995) \\
\hline HUVEC & $24 \mathrm{~h}$ & 0.1 & $\uparrow 16 \%$ & NA & NA & (Mikkola et al., 1996) \\
\hline HUVEC & $24 \mathrm{~h}$ & 1 & $\uparrow 78 \%$ & $\leftrightarrow$ & $\uparrow$ & $\begin{array}{c}\text { (Akarasereenont et al., } \\
\text { 2000) }\end{array}$ \\
\hline HUVEC & $24 \mathrm{~h}$ & 1 & $\uparrow 30 \%$ & $\uparrow$ & $\leftrightarrow$ & (Sobrino et al., 2009) \\
\hline HUVEC & $24 \mathrm{~h}$ & 10 & $\uparrow 33 \%$ & $\uparrow$ & $\leftrightarrow$ & (Sobrino et al., 2010) \\
\hline Human coronary EC & $24 \mathrm{~h}$ & 100 & $\uparrow 45 \%$ & NA & NA & (Mueck et al., 2002) \\
\hline Bovine coronary EC & $24 \mathrm{~h}$ & 1 & $\downarrow 83 \%$ & $\leftrightarrow$ & $\leftrightarrow$ & (Stewart et al., 1999) \\
\hline Ovine fetal PAEC & $48 \mathrm{~h}$ & 10 & $\uparrow 64 \%$ & $\uparrow$ & NA & (Jun et al., 1998) \\
\hline
\end{tabular}

Table 1. Summary of estradiol effects on cultured cell production of prostacyclin. $E_{2}$ : concentration of estradiol in nM. Prostacyclin production is expressed as increased $(\uparrow)$ or decreased $(\downarrow)$ percentage of control values. COX-1 and COX-2 expression: increased $(\uparrow)$, decreased $(\downarrow)$, unchanged $(\leftrightarrow)$ or not available (NA). PAEC: pulmonary artery endothelial cells. HUVEC: human umbilical vein endothelial cells. EC: endothelial cells.

\subsection{Delayed (genomic) effects of estrogens on prostanoids vascular production}

Estrogen also exerts vascular delayed effects on the metabolism of prostaglandins and the activity of COX, as has been demonstrated in studies performed both in cultured cells, as well as in isolated vascular preparations.

A time-course analysis performed in HUVEC, demonstrates that estradiol effects on prostacyclin production were evident only after 8 or 24 hours (10 and $1 \mathrm{nM}$ estradiol, respectively), suggesting an ER-mediated genomic effect (Sobrino et al., 2010). Moreover, physiological concentrations of estradiol stimulate the production of prostaglandins, mainly 
prostacyclin, in a variety of cultured endothelial cells, such as ovine fetal PAEC (Jun et al., 1998), HUVEC (Mikkola et al., 1995; Mikkola et al., 1996; Akarasereenont et al., 2000; Sobrino et al., 2010), and human coronary endothelial cell (Mueck et al., 2002). In the vast majority of experiments, cells were exposed to estradiol during 24-48 hours, and the increase of prostacyclin above control values ranged from $16 \%$ to $78 \%$ (Table 1 ).

In addition, it has been shown that estradiol stimulates production of prostaglandins in a variety of preparations of arteries, including ovine uterine arteries (Vagnoni \& Magness, 1998; Janowiak et al., 1998; Habermehl et al., 2000), mesenteric arteries from ovariectomized rats (Davidge \& Zhang, 1998; Armstrong et al., 2002), rat cerebral blood vessels (Ospina et al., 2002; Ospina et al., 2003), and aorta from ovariectomized monkeys (O'Sullivan et al., 2001). The increase of prostacyclin production is of a similar magnitude to that obtained with cultured endothelial cells.

Concerning endothelial production of thromboxane $\mathrm{A}_{2}$ under estradiol, the literature indirectly suggests that estrogen would have a beneficial effect by decreasing the production of thrombogenic compounds. In men, there is a decrease in the formation of thromboxane $\mathrm{A}_{2}$ after the use of high dosage intra-muscular estrogen therapy (Henriksson et al., 1996). Moreover, the ratio of in vivo prostacyclin to thromboxane $\mathrm{A}_{2}$ formation increases 2-fold during estrogen replacement therapy (Mueck et al., 2001). Nevertheless, it has also been documented that estrogen increases platelet activation with the liberation of thromboxane $\mathrm{A}_{2}$ in women treated with hormone replacement therapy (Oliveira et al., 2005) and that estrogen enhances the constrictor prostanoid function in female rat aorta (Li et al., 2008). However, in cultured endothelial cells, thromboxane $A_{2}$ production remains unchanged when measured after exposure to estradiol (Sobrino et al., 2010).

The regulatory role of estradiol on the biosynthesis pathway of prostanoids in endothelium (Figure 1) has been scarcely studied, with the only exception of COX-1 and COX-2 expressions. Concerning the first enzyme, soluble phospholipase $\mathrm{A}_{2}$ is highly expressed in HUVEC and umbilical smooth muscle cells (Ost et al., 1998), but it does not appear to be regulated by estradiol. Phospholipase $\mathrm{A}_{2}$ expression remains unchanged after exposure to estradiol in HUVEC (Sobrino et al., 2010) or in human myometrial cells prepared from second trimester pregnant women (Korita et al., 2004).

The roles of COX-1 and/or COX-2 isoenzymes in endothelial cells exposed to estradiol have been studied in some cases, and both enzymes have been implicated in estradiol effects. In ovine fetal PAEC after exposure to estradiol, both COX-1 mRNA and protein expressions were up-regulated (Jun et al., 1998), whereas in HUVEC estradiol only induces COX-2 expression protein (Akarasereenont et al., 2000). Genome-wide analysis performed in HUVEC exposed to estradiol for 24 hours demonstrated that COX-1 was among the $5 \%$ of proteins which expression was changed more than 1.5 fold-times compared to controls, data that was verified by western blot analysis (Sobrino et al., 2009).

Prostacyclin increased levels after vessel stimulation with estradiol have been mainly associated with enhanced expression of COX-1. In this way, COX-1 protein content is increased in rat (Ospina et al., 2002) and mice (Geary et al., 2001) cerebral blood vessels, and in ovine uterine arteries in response to treatment with estrogen (Rupnow et al., 2002). Indeed, COX-1 (but not COX-2) expression is increased in the endothelium of the ovine uterine artery during the follicular phase of the ovarian cycle and during pregnancy, where estrogen levels are highest (Janowiak et al., 1998; Habermehl et al., 2000). In spite of the classic consideration of COX-2 as an inducible enzyme, it seems that COX-2 does not contribute to the estradiol-increased prostacyclin production. Estrogen has even been found 
to decrease COX-2 expression in mesenteric arteries from ovariectomized aged rats (Armstrong et al., 2002).

However, similar experiments have occasionally produced contradictory results. Exposure of culture bovine coronary microvascular endothelial cells to physiological concentrations of estradiol for 24 hours reduced both prostacyclin and thromboxane $\mathrm{A}_{2}$ production (Stewart et al., 1999). In the case of whole tissue experiments, arteries respond in a different way to estradiol. This is the case of artery segments from different vascular beds (thoracic aorta, pulmonary artery, ear artery and coronary arteries) from adult male rabbits in which estradiol may cause both vasorelaxation and vasoconstriction (Saetrum et al., 2002). Moreover, in thoracic aorta the contractile effects of estrogen are mediated through the release of vasoconstrictor prostaglandins (Saetrum et al., 2002).

These discrepancies could indicate a difference in the effects of estrogen depending on its previous serum concentration, the reproductive condition of the animal and/or the vascular bed being studied (Armstrong et al., 2002; Saetrum et al., 2002; Tostes et al., 2003).

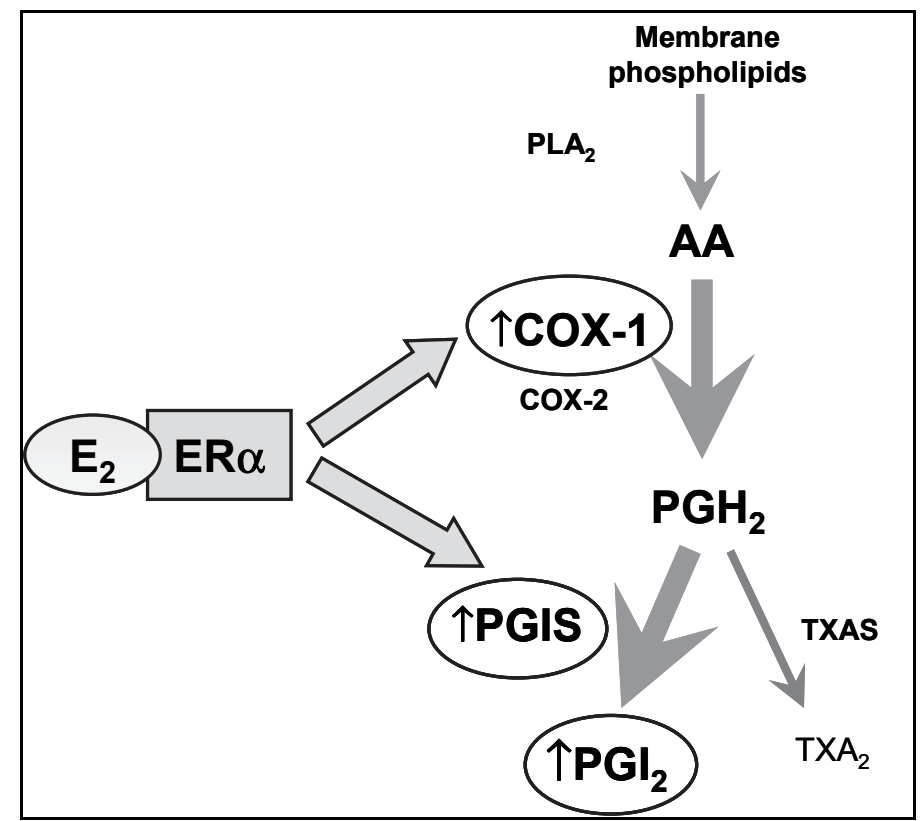

Fig. 2. Estradiol-induced modifications on prostanoid pathway through ERa. Estradiol $\left(\mathrm{E}_{2}\right)$, acting on ERa, increased cyclooxygenase-1 (COX-1) and prostacyclin synthase (PGIS) expression, resulting in an increased prostacyclin $\left(\mathrm{PGI}_{2}\right)$ production. Phospholipase $\mathrm{A}_{2}$, cyclooxygenase-2 (COX-2) and thromboxane synthase (TXAS) expressions, along with thromboxane $\mathrm{A}_{2}$ production $\left(\mathrm{TX}_{2}\right)$, remained unchanged after exposure to estradiol.

The regulatory actions of estradiol on the prostanoids biosynthesis pathway are mediated through ER activation. The use of ICI182780, a non-selective ER-antagonists, completely blocks estradiol-stimulated prostacyclin production in ovine fetal PAEC (Jun et al., 1998), HUVEC (Sobrino et al., 2009), and tamoxifen blocked it in HUVEC (Mikkola et al., 1995; Mikkola et al., 1996). 
Moreover, data support a specific role for ERa on estradiol-stimulated prostacyclin production. Recently, selective ERa agonist 1,3,5-tris(4-hydroxyphenyl)-4-propyl-1h-pyrazole (PPT), selective ER $\beta$ agonist (diarylpropionitril; DPN), and selective ERa antagonist, methylpiperidino-pyrazole (MPP), have become available (Krom et al., 2007). With their use, it has been demonstrated that estradiol increased prostacyclin production, and COX-1 and prostacyclin synthase protein and gene expressions through ERa, whereas COX-2, phospholipases and thromboxane synthase expression remained unaltered (Sobrino et al., 2010). The regulatory role of estradiol through ERa is supported by other studies. Estradiol increases levels of COX-1 in cerebral blood vessels from wild-type mice but was ineffective in ERa knockout mice (Geary et al., 2001) and also increases COX-1 expression through ERa in ovine endothelial cells transfected with the human COX-1 promoter (Gibson et al., 2005).

\section{Conclusion}

Remarkable progress has been made in elucidating the effects of estrogens on the vascular system, and the cellular and molecular mechanisms by which those effects are achieved. The analysis of published data supports estradiol increases prostacyclin vascular production in accordance with experimental and clinical research. This effect seems to be mediated mainly through ERa-dependent pathways which involve an increase in COX-1 and, in some cases, COX-2 activation and/or expression, and an augment in prostacyclin synthase expression, without affecting thromboxane A2 production. As a consequence, estradiol may reduce vascular tone and improve endothelium-dependent vasodilation (Figure 2).

\section{Acknowledgments}

Supported by the Spanish Ministerio de Ciencia e Innovación, Instituto de Salud Carlos III (grants FIS PI10/00518 and Red HERACLES RD06/0009/0005), Consellería de Sanidad (grants AP 117/2010 and GE 021/2010).

\section{References}

Abu-Taha, M., Rius, C., Hermenegildo, C., Noguera, I., Cerda-Nicolas, J.M., Issekutz, A.C., Jose, P.J., Cortijo, J., Morcillo, E.J. \& Sanz, M.J. (2009). Menopause and Ovariectomy Cause a Low Grade of Systemic Inflammation that May Be Prevented by Chronic Treatment with Low Doses of Estrogen or Losartan. J. Immunol. 183, 1393-1402.

Akarasereenont, P., Techatraisak, K., Thaworn, A. \& Chotewuttakorn, S. (2000). The induction of cyclooxygenase-2 by 17 beta-estradiol in endothelial cells is mediated through protein kinase C. Inflamm. Res. 49, 460-465.

Akishita, M., Kozaki, K., Eto, M., Yoshizumi, M., Ishikawa, M., Toba, K., Orimo, H. \& Ouchi, Y. (1998). Estrogen attenuates endothelin-1 production by bovine endothelial cells via estrogen receptor. Biochem. Biophys. Res. Commun. 251, 17-21.

Alvarez, A., Hermenegildo, C., Issekutz, A.C., Esplugues, J.V. \& Sanz, M.J. (2002). Estrogens inhibit angiotensin II-induced leukocyte-endothelial cell interactions in vivo via rapid endothelial nitric oxide synthase and cyclooxygenase activation. Circ. Res. 91, $1142-1150$. 
Armstrong, S.J., Zhang, Y., Stewart, K.G. \& Davidge, S.T. (2002). Estrogen replacement reduces PGHS-2-dependent vasoconstriction in the aged rat. Am. J. Physiol. Heart. Circ. Physiol. 283, H893-H898.

Arnal, J.F., Fontaine, C., Billon-Gales, A., Favre, J., Laurell, H., Lenfant, F. \& Gourdy, P. (2010). Estrogen Receptors and Endothelium. Arterioscler. Thromb. Vasc. Biol. 30, 1506-1512.

Barrett-Connor, E., Grady, D. (1998). Hormone replacement therapy, heart disease, and other considerations. Annu. Rev. Pub. Health. 19, 55-72.

Calkin, A.C., Sudhir, K., Honisett, S., Williams, M.R., Dawood, T. \& Komesaroff, P.A. (2002). Rapid potentiation of endothelium-dependent vasodilation by estradiol in postmenopausal women is mediated via cyclooxygenase 2. J. Clin. Endocrinol. Metab. 87, 5072-5075.

Camacho, M., Vila, L. (2000). Transcellular formation of thromboxane A2 in mixed incubations of endothelial cells and aspirin-treated platelets strongly depends on the prostaglandin I-synthase activity. Thromb. Res. 99, 155-164.

Cano, A., Hermenegildo, C. (2000). Modulation of the oestrogen receptor: a process with distinct susceptible steps. Hum. Reprod. Update. 6, 207-211.

Cano, A., Hermenegildo, C., Oviedo, P. \& Tarin, J.J. (2007). The risk for cardiovascular disease in women: from estrogens to selective estrogen receptor modulators. Front. Biosci. 12, 49-68.

Caulin-Glaser, T., Watson, C.A., Pardi, R. \& Bender, J.R. (1996). Effects of 17beta-estradiol on cytokine-induced endothelial cell adhesion molecule expression. J. Clin. Invest. 98, 36-42.

Cheng, H.F., Harris, R.C. (2004). Cyclooxygenases, the Kidney, and Hypertension. Hypertension 43, 525-530.

Chester, A.H., Jiang, C., Borland, J.A., Yacoub, M.H. \& Collins, P. (1995). Oestrogen relaxes human epicardial coronary arteries through non-endothelium-dependent mechanisms. Coron. Artery Dis. 6, 417-422.

Chow, R.W.Y., Handelsman, D.J. \& Ng, M.K.C. (2010). Rapid Actions of Sex Steroids in the Endothelium. Endocrinology 151, 2411-2422.

Cipollone, F., Cicolini, G. \& Bucci, M. (2008). Cyclooxygenase and prostaglandin synthases in atherosclerosis: Recent insights and future perspectives. Pharmacol. Ther.118, 161-180.

Davidge, S.T. (2001). Prostaglandin H Synthase and Vascular Function. Circ. Res. 89, 650-660.

Davidge, S.T., Baker, P.N., McLaughlin, M.K. \& Roberts, J.M. (1995). Nitric oxide produced by endothelial cells increases production of eicosanoids through activation of prostaglandin H synthase. Circ. Res. 77, 274-283.

Davidge, S.T., Zhang, Y. (1998). Estrogen replacement suppresses a prostaglandin H synthase-dependent vasoconstrictor in rat mesenteric arteries. Circ. Res. 83, 388-395.

DeWitt, D.L., Day, J.S., Sonnenburg, W.K. \& Smith, W.L. (1983). Concentrations of prostaglandin endoperoxide synthase and prostaglandin I2 synthase in the endothelium and smooth muscle of bovine aorta. J. Clin. Invest. 72, 1882-1888.

Doroudi, R., Gan, LM., Selin Sjogren, L. \& Jern, S. (2000). Effects of shear stress on eicosanoid gene expression and metabolite production in vascular endothelium as studied in a novel biomechanical perfusion model. Biochem. Biophys. Res. Commun. 269, 257-264.

Farhat, M.Y., Lavigne, M.C. \& Ramwell, P.W. (1996). The vascular protective effects of estrogen. FASEB J. 10, 615-624. 
Favre, J., Gao, J., Henry, J.P., Remy-Jouet, I., Fourquaux, I., Billon-Gales, A., Thuillez, C., Arnal, J.F., Lenfant, F. \& Richard, V. (2010). Endothelial Estrogen Receptor \{alpha\} Plays an Essential Role in the Coronary and Myocardial Protective Effects of Estradiol in Ischemia/Reperfusion. Arterioscler. Thromb. Vasc. Biol. 30, 2562-2567.

Feletou, M., Cohen, R.A., Vanhoutte, P.M. \& Verbeuren, T.J. (2010). TP receptors and oxidative stress hand in hand from endothelial dysfunction to atherosclerosis. Adv. Pharmacol 60, 85-106.

Fetalvero, K.M., Martin, K.A. \& Hwa, J. (2007). Cardioprotective prostacyclin signaling in vascular smooth muscle. Prostaglandins Lipid Mediators 82, 109-118.

Filipe, C., Lam Shang Leen, L., Brouchet, L., Billon, A., Benouaich, V., Fontaine, V., Gourdy, P., Lenfant, F., Arnal, J.F., Gadeau, A.P. \& Laurell, H. (2008). Estradiol accelerates endothelial healing through the retrograde commitment of uninjured endothelium. Am. J. Physiol. Heart Circ. Physiol. 294, H2822-H2830.

FitzGerald, G.A. (2002). Cardiovascular pharmacology of nonselective nonsteroidal antiinflammatory drugs and coxibs: clinical considerations. Am. J. Cardiol. 89, 26-32.

Geary, G.G., McNeill, A.M., Ospina, J.A., Krause, D.N., Korach, K.S. \& Duckles, S.P. (2001). Cerebrovascular NOS and cyclooxygenase are unaffected by estrogen in mice lacking estrogen receptor-alpha. J. Appl. Physiol. 91, 2391-2399.

Gibson, L.L., Hahner, L., Osborne-Lawrence, S., German, Z., Wu, K.K., Chambliss, K.L. \& Shaul, P.W. (2005). Molecular Basis of Estrogen-Induced Cyclooxygenase Type 1 Upregulation in Endothelial Cells. Circ. Res. 96, 518-525.

Grady, D., Herrington, D., Bittner, V., Blumenthal, R., Davidson, M., Hlatky, M., Hsia, J., Hulley, S., Herd, A., Khan, S., Newby, L.K., Waters, D., Vittinghoff, E. \& Wenger, N. (2002). Cardiovascular disease outcomes during 6.8 years of hormone therapy: Heart and Estrogen/progestin Replacement Study follow-up (HERS II). JAMA 288, 49-57.

Habermehl, D.A., Janowiak, M.A., Vagnoni, K.E., Bird, I.M. \& Magness, R.R. (2000). Endothelial vasodilator production by uterine and systemic arteries. IV. Cyclooxygenase isoform expression during the ovarian cycle and pregnancy in sheep. Biol. Reprod. 62, 781-788.

Henriksson, P., Stege, R. \& Green, K. (1996). Profound decrease of in vivo formation of thromboxane during oestrogen therapy. Eur. J. Clin. Invest. 26, 1186-1188.

Hermenegildo, C., Garcia-Martinez, M.C., Tarin, J.J. \& Cano, A. (2002). Estradiol reduces F2alpha -isoprostane production in cultured human endothelial cells. Am. J. Physiol Heart Circ. Physiol. 283, H2644-H2649.

Hulley, S., Grady, D., Bush, T., Furberg, C., Herrington, D., Riggs, B. \& Vittinghoff, E. (1998). Randomized trial of estrogen plus progestin for secondary prevention of coronary heart disease in postmenopausal women. Heart and Estrogen/progestin Replacement Study (HERS) Research Group. JAMA 280, 605-613.

Janowiak, M.A., Magness, R.R., Habermehl, D.A. \& Bird, I.M. (1998). Pregnancy increases ovine uterine artery endothelial cyclooxygenase-1 expression. Endocrinology 139, 765-771.

Jun, S.S., Chen, Z., Pace, M.C. \& Shaul, P.W. (1998). Estrogen upregulates cyclooxygenase-1 gene expression in ovine fetal pulmonary artery endothelium. J. Clin. Invest. 102, 176-183.

Karas, R.H., Patterson, B.L. \& Mendelsohn, M.E. (1994). Human vascular smooth muscle cells contain functional estrogen receptor. Circulation 89, 1943-1950. 
Kim, J.J., Wang, J., Bambra, C., Das, S.K., Dey, S.K. \& Fazleabas, A.T. (1999). Expression of cyclooxygenase- 1 and -2 in the baboon endometrium during the menstrual cycle and pregnancy. Endocrinology 140, 2672-2678.

Kim-Schulze, S., McGowan, K.A., Hubchak, S.C., Cid, M.C., Martin, M.B., Kleinman, H.K., Greene, G.L. \& Schnaper, H.W. (1996). Expression of an estrogen receptor by human coronary artery and umbilical vein endothelial cells. Circulation 94, 1402-1407.

Korita, D., Itoh, H., Sagawa, N., Yura, S., Yoshida, M., Kakui, K., Takemura, M. \& Fujii, S. (2004). 17[beta]-estradiol up-regulates prostacyclin production in cultured human uterine myometrial cells via augmentation of both cyclooxygenase- 1 and prostacyclin synthase expression. J. Soc. Gynecol.c Invest. 11, 457-464.

Krom, Y.D., Pires, N.M.M., Jukema, J.W., de Vries, M.R., Frants, R.R., Havekes, L.M., van Dijk, K.W. \& Quax, P.H.A. (2007). Inhibition of neointima formation by local delivery of estrogen receptor alpha and beta specific agonists. Cardiovasc. Res. 73, 217-226.

Levin, E.R. (2009). G Protein-Coupled Receptor 30: Estrogen Receptor or Collaborator? Endocrinology 150, 1563-1565.

Li, M., Kuo, L. \& Stallone, J.N. (2008). Estrogen potentiates constrictor prostanoid function in female rat aorta by upregulation of cyclooxygenase- 2 and thromboxane pathway expression. Am. J. Physiol. Heart Circ. Physiol. 294, H2444-H2455.

Linton, M.F., Fazio, S. (2002). Cyclooxygenase-2 and atherosclerosis. Curr. Opin. Lipidol. 13, 497-504.

McAdam, B.F., Catella-Lawson, F., Mardini, I.A., Kapoor, S., Lawson, J.A. \& FitzGerald, G.A. (1999). Systemic biosynthesis of prostacyclin by cyclooxygenase (COX)-2: the human pharmacology of a selective inhibitor of COX-2. Proc. Natl. Acad. Sci. USA 96, 272-277.

Mendelsohn, M.E., Karas, R.H. (1999). The protective effects of estrogen on the cardiovascular system. N. Engl. J. Med. 340, 1801-1811.

Mendelsohn, M.E., Karas, R.H. (2010). Rapid progress for non-nuclear estrogen receptor signaling. J. Clin. Invest. 120, 2277-2279.

Mikkola, T., Ranta, V., Orpana, A., Ylikorkala, O. \& Viinikka, L. (1996). Effect of physiological concentrations of estradiol on PGI2 and NO in endothelial cells. Maturitas 25, 141-147.

Mikkola, T., Turunen, P., Avela, K., Orpana, A., Viinikka, L. \& Ylikorkala, O. (1995). 17 betaestradiol stimulates prostacyclin, but not endothelin-1, production in human vascular endothelial cells. J. Clin. Endocrinol. Metab. 80, 1832-1836.

Moncada, S., Vane, J.R. (1978). Pharmacology and endogenous roles of prostaglandin endoperoxides, thromboxane A2, and prostacyclin. Pharmacol. Rev. 30, 293-331.

Monsalve, E., Oviedo, P.J., Garcia-Perez, M.A., Tarin, J.J., Cano, A. \& Hermenegildo, C. (2007). Estradiol counteracts oxidized LDL-induced asymmetric dimethylarginine production by cultured human endothelial cells. Cardiovasc. Res. 73, 66-72.

Mueck, A.O., Seeger, H., Ludtke, R., Graser, T. \& Wallwiener, D. (2001). Effect on biochemical vasoactive markers during postmenopausal hormone replacement therapy: estradiol versus estradiol/dienogest. Maturitas 38, 305-313.

Mueck, A.O., Seeger, H. \& Wallwiener, D. (2002). Medroxyprogesterone acetate versus norethisterone: effect on estradiol-induced changes of markers for endothelial function and atherosclerotic plaque characteristics in human female coronary endothelial cell cultures. Menopause 9, 273-281. 
Myers, S.I., Turnage, R.H., Bartula, L., Kalley, B. \& Meng, Y. (1996). Estrogen increases male rat aortic endothelial cell (RAEC) PGI2 release. Prostaglandins Leukot. Essent. Fatty Acids 54, 403-409.

Naderali, E.K., Smith, S.L., Doyle, P.J. \& Williams, G. (2001). Vasorelaxant effects of oestradiols on guinea pigs: a role for gender differences. Eur. J. Clin. Invest. 31, 215-220.

Nakahata, N. (2008). Thromboxane A2: Physiology/pathophysiology, cellular signal transduction and pharmacology. Pharmacol. Ther. 118, 18-35.

O'Sullivan, M.G., Goodrich, J.A. \& Adams, M.R. (2001). Increased prostacyclin synthesis by atherosclerotic arteries from estrogen-treated monkeys. Life Sci. 69, 395-401.

Oliveira, R.L., Aldrighi, J.M., Gebara, O.E., Rocha, T.R.F., D'Amico, E., Rosano, G.M.C. \& Ramires, J.A. (2005). Postmenopausal hormone replacement therapy increases plasmatic thromboxane [beta]2. Int. J. Cardiol. 99, 449-454.

Ospina, J.A., Duckles, S.P. \& Krause, D.N. (2003). 17beta-Estradiol decreases vascular tone in cerebral arteries by shifting COX-dependent vasoconstriction to vasodilation. Am. J. Physiol. Heart. Circ. Physiol. 285, H241-H250.

Ospina, J.A., Krause, D.N. \& Duckles, S.P. (2002). 17beta-estradiol increases rat cerebrovascular prostacyclin synthesis by elevating cyclooxygenase-1 and prostacyclin synthase. Stroke 33, 600-605.

Ost, M., Uhl, E., Carlsson, M., Gidlof, A., Soderkvist, P. \& Sirsjo, A. (1998). Expression of mRNA for phospholipase A2, cyclooxygenases, and lipoxygenases in cultured human umbilical vascular endothelial and smooth muscle cells and in biopsies from umbilical arteries and veins. J. Vasc. Res. 35, 150-155.

Oviedo, P.J., Sobrino, A., Laguna-Fernandez, A., Novella, S., TarÆn, J.J., GarcÆaa-Pqrez, M.A., SanchÆs, J., Cano, A. \& Hermenegildo, C. (2011). Estradiol induces endothelial cell migration and proliferation through estrogen receptor-enhanced RhoA/ROCK pathway. Mol. Cell. Endocrinol. 335, 96-103.

Pare, G., Krust, A., Karas, R.H., Dupont, S., Aronovitz, M., Chambon, P. \& Mendelsohn, M.E. (2002). Estrogen receptor-alpha mediates the protective effects of estrogen against vascular injury. Circ. Res. 90, 1087-1092.

Parente, L., Perretti, M. (2003). Advances in the pathophysiology of constitutive and inducible cyclooxygenases: two enzymes in the spotlight. Biochem. Pharmacol. 65, 153-159.

Patrignani, P., Sciulli, M.G., Manarini, S., Santini, G., Cerletti, C. \& Evangelista, V. (1999). COX-2 is not involved in thromboxane biosynthesis by activated human platelets. J. Physiol. Pharmacol. 50, 661-667.

Pedram, A., Razandi, M., Aitkenhead, M., Hughes, C.C. \& Levin, E.R. (2002). Integration of the Non-genomic and Genomic Actions of Estrogen. Membrane-initiated signaling by steroid to transcription and cell biology. J Biol. Chem. 277, 50768-50775.

Razandi, M., Pedram, A. \& Levin, E.R. (2000). Estrogen Signals to the Preservation of Endothelial Cell Form and Function. J. Biol. Chem. 275, 38540-38546.

Register, T.C., Adams, M.R. (1998). Coronary artery and cultured aortic smooth muscle cells express mRNA for both the classical estrogen receptor and the newly described estrogen receptor beta. J. Steroid Biochem. Mol. Biol. 64, 187-191.

Ross, R. (1999). Atherosclerosis: an inflammatory disease. N. Engl. J Med. 340, 115-126.

Rubanyi, G.M., Johns, A. \& Kauser, K. (2002). Effect of estrogen on endothelial function and angiogenesis. Vascul. Pharmacol. 38, 89-98.

Rupnow, H.L., Phernetton, T.M., Modrick, M.L., Wiltbank, M.C., Bird, I.M. \& Magness, R.R. (2002). Endothelial vasodilator production by uterine and systemic arteries. VIII. 
Estrogen and progesterone effects on cPLA2, COX-1, and PGIS protein expression. Biol. Reprod. 66, 468-474.

Sader, M.A., Celermajer, D.S. (2002). Endothelial function, vascular reactivity and gender differences in the cardiovascular system. Cardiovasc. Res. 53, 597-604.

Saetrum, O.O., Duckles, S.P. \& Krause, D.N. (2002). Regional differences in the effect of oestrogen on vascular tone in isolated rabbit arteries. Pharmacol. Toxicol. 91, 77-82.

Salom, J.B., Burguete, M.C., Perez-Asensio, F.J., Centeno, J.M., Torregrosa, G. \& Alborch, E. (2002). Acute relaxant effects of 17-beta-estradiol through non-genomic mechanisms in rabbit carotid artery. Steroids 67, 339-346.

Schildknecht, S., Ullrich, V. (2009). Peroxynitrite as regulator of vascular prostanoid synthesis. Arch. Biochem. Biophys. 484, 183-189.

Sellers, M.M., Stallone, J.N. (2008). Sympathy for the devil: the role of thromboxane in the regulation of vascular tone and blood pressure. Am. J. Physiol. Heart Circ. Physiol. 294, H1978-H1986.

Sherman, T.S., Chambliss, K.L., Gibson, L.L., Pace, M.C., Mendelsohn, M.E., Pfister, S.L. \& Shaul, P.W. (2002). Estrogen acutely activates prostacyclin synthesis in ovine fetal pulmonary artery endothelium. Am. J. Respir. Cell Mol. Biol. 26, 610-616.

Shwaery, G.T., Vita, J.A. \& Keaney, J.F.J. (1998). Antioxidant protection of LDL by physiologic concentrations of estrogens is specific for 17-beta-estradiol. Atherosclerosis 138, 255-262.

Simoncini, T. (2009). Mechanisms of action of estrogen receptors in vascular cells: relevance for menopause and aging. Climacteric 12 Suppl 1, 6-11.

Simoncini, T., Mannella, P., Fornari, L., Caruso, A., Varone, G. \& Genazzani, A.R. (2004). Genomic and non-genomic effects of estrogens on endothelial cells. Steroids 69, 537542.

Simoncini, T., Scorticati, C., Mannella, P., Fadiel, A., Giretti, M.S., Fu, X.D., Baldacci, C., Garibaldi, S., Caruso, A., Fornari, L., Naftolin, F. \& Genazzani, A.R. (2006). Estrogen Receptor \{alpha\} Interacts with G\{alpha\}13 to Drive Actin Remodeling and Endothelial Cell Migration via the RhoA/Rho Kinase/Moesin Pathway. Mol. Endocrinol. 20, 1756-1771.

Smith, W.L., DeWitt, D.L. \& Garavito, R.M. (2000). Cyclooxygenases: structural, cellular, and molecular biology. Annu. Rev. Biochem. 69, 145-182.

Sobrino, A., Mata, M., Laguna-Fernandez, A., Novella, S., Oviedo, P.J., Garcia-Perez, M.A., Tarin, J.J., Cano, A. \& Hermenegildo, C. (2009). Estradiol Stimulates Vasodilatory and Metabolic Pathways in Cultured Human Endothelial Cells. PLoS ONE 4, e8242.

Sobrino, A., Oviedo, P.J., Novella, S., Laguna-Fernandez, A., Bueno, C., Garcia-Perez, M.A., Tarin, J.J., Cano, A. \& Hermenegildo, C. (2010). Estradiol selectively stimulates endothelial prostacyclin production through estrogen receptor a. J. Mol. Endocrinol. $44,237-246$.

Spyridopoulos, I., Sullivan, A.B., Kearney, M., Isner, J.M. \& Losordo, D.W. (1997). Estrogenreceptor-mediated inhibition of human endothelial cell apoptosis. Estradiol as a survival factor. Circulation 95, 1505-1514.

Stewart, K.G., Zhang, Y. \& Davidge, S.T. (1999). Estrogen decreases prostaglandin H synthase products from endothelial cells. J. Soc. Gynecol. Investig. 6, 322-327.

Su, E.J., Lin, Z.H., Zeine, R., Yin, P., Reierstad, S., Innes, J.E. \& Bulun, S.E. (2009). Estrogen receptor-beta mediates cyclooxygenase-2 expression and vascular prostanoid levels in human placental villous endothelial cells. Am. J. Obstet. Gynecol. 200, 427. 
Sudhir, K., Chou, T.M., Messina, L.M., Hutchison, S.J., Korach, K.S., Chatterjee, K. \& Rubanyi, G.M. (1997). Endothelial dysfunction in a man with disruptive mutation in oestrogen-receptor gene. Lancet 349, 1146-1147.

Teoh, H., Quan, A., Leung, S.W. \& Man, R.Y. (2000). Differential effects of 17beta-estradiol and testosterone on the contractile responses of porcine coronary arteries. Br. J. Pharmacol. 129, 1301-1308.

Tep-areenan, P., Kendall, D.A. \& Randall, M.D. (2003). Mechanisms of vasorelaxation to 17[beta]-oestradiol in rat arteries. Eur. J. Pharmacol. 476, 139-149.

Tostes, R.C., Nigro, D., Fortes, Z.B. \& Carvalho, M.H. (2003). Effects of estrogen on the vascular system. Braz. J. Med. Biol. Res. 36, 1143-1158.

Toth, B., Scholz, C., Saadat, G., Geller, A., Schulze, S., Mylonas, I., Friese, K. \& Jeschke, U. (2008). Estrogen receptor modulators and estrogen receptor beta immunolabelling in human umbilical vein endothelial cells. Acta Histochem. 111, 508-519.

Traupe, T., Stettler, C.D., Li, H., Haas, E., Bhattacharya, I., Minotti, R. \& Barton, M. (2007). Distinct Roles of Estrogen Receptors \{alpha\} and \{beta\} Mediating Acute Vasodilation of Epicardial Coronary Arteries. Hypertension 49, 1364-1370.

Tsuboi, K., Sugimoto, Y. \& Ichikawa, A. (2002). Prostanoid receptor subtypes. Prostaglandins Other Lipid Mediat. 68-69, 535-556.

Turgeon, J.L., Carr, M.C., Maki, P.M., Mendelsohn, M.E. \& Wise, P.M. (2006). Complex Actions of Sex Steroids in Adipose Tissue, the Cardiovascular System, and Brain: Insights from Basic Science and Clinical Studies. Endocr. Rev. 27, 575-605.

Vagnoni, K.E., Magness, R.R. (1998). Estrogen and lipopolysaccharide stimulation of prostacyclin production and the levels of cyclooxygenase and nitric oxide synthase in ovine uterine arteries. Biol. Reprod. 59, 1008-1015.

Vane, J.R., Bakhle, Y.S. \& Botting, R.M. (1998). Cyclooxygenases 1 and 2. Annu. Rev. Pharmacol. Toxicol. 38, 97-120.

Vanhoutte, P.M. (2009). COX-1 and Vascular Disease. Clin Pharmacol Ther 86, 212-215.

Vanhoutte, P.M., Shimokawa, H., Tang, E.H. \& Feletou, M. (2009). Endothelial dysfunction and vascular disease. Acta Physiol (Oxf) 196, 193-222.

Vapaatalo, H., Mervaala, E. (2001). Clinically important factors influencing endothelial function. Med. Sci. Monit. 7, 1075-1085.

Venkov, C.D., Rankin, A.B. \& Vaughan, D.E. (1996). Identification of authentic estrogen receptor in cultured endothelial cells. A potential mechanism for steroid hormone regulation of endothelial function. Circulation 94, 727-733.

Wagner, A.H., Schroeter, M.R. \& Hecker, M. (2001). 17beta-estradiol inhibition of NADPH oxidase expression in human endothelial cells. FASEB J. 15, 2121-2130.

Weir, M.R., Sperling, R.S., Reicin, A. \& Gertz, B.J. (2003). Selective COX-2 inhibition and cardiovascular effects: a review of the rofecoxib development program. Am. Heart J. $146,591-604$.

Wu, Q., Chambliss, K., Umetani, M., Mineo, C. \& Shaul, P.W. (2011). Non-nuclear Estrogen Receptor Signaling in Endothelium. J. Biol. Chem .(in press). DOI: 10.1074/jbc.R110.191791

Zhu, Y., Bian, Z., Lu, P., Karas, R.H., Bao, L., Cox, D., Hodgin, J., Shaul, P.W., Thoren, P., Smithies, O., Gustafsson, J.A. \& Mendelsohn, M.E. (2002). Abnormal Vascular Function and Hypertension in Mice Deficient in Estrogen Receptor beta. Science 295, 505-508.

Zou, M.H., Cohen, R. \& Ullrich, V. (2004). Peroxynitrite and vascular endothelial dysfunction in diabetes mellitus. Endothelium 11, 89-97. 


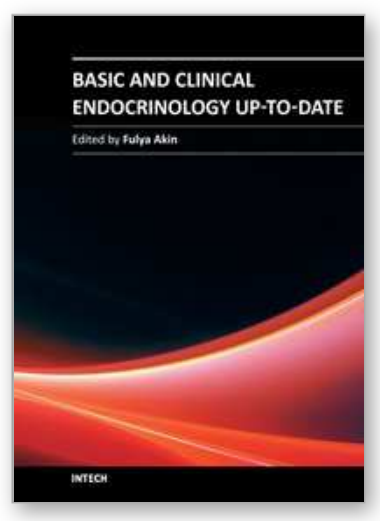

\author{
Basic and Clinical Endocrinology Up-to-Date \\ Edited by Dr. Fulya Akin
}

ISBN 978-953-307-340-8

Hard cover, 350 pages

Publisher InTech

Published online 17, October, 2011

Published in print edition October, 2011

This book provides the most up-to-date information on the basic and clinical aspects of endocrinology. It offers both researchers and clinicians experts, gold-standard analysis of endocrine research and translation into the treatment of diseases such as insulinoma, endocrine disease in pregnancy and steroid induced osteoporosis. Investigates both the endocrine functions of the kidneys and how the kidney acts as a target for hormones from other organ systems. Presents a uniquely comprehensive look at all aspects of endocrine changes in pregnancy and cardiovascular effects of androgens.

\title{
How to reference
}

In order to correctly reference this scholarly work, feel free to copy and paste the following:

Susana Novella and Carlos Hermenegildo (2011). Estradiol Regulation of Prostanoids Production in Endothelium, Basic and Clinical Endocrinology Up-to-Date, Dr. Fulya Akin (Ed.), ISBN: 978-953-307-340-8, InTech, Available from: http://www.intechopen.com/books/basic-and-clinical-endocrinology-up-todate/estradiol-regulation-of-prostanoids-production-in-endothelium

\section{INTECH}

open science | open minds

\section{InTech Europe}

University Campus STeP Ri

Slavka Krautzeka 83/A

51000 Rijeka, Croatia

Phone: +385 (51) 770447

Fax: +385 (51) 686166

www.intechopen.com

\section{InTech China}

Unit 405, Office Block, Hotel Equatorial Shanghai

No.65, Yan An Road (West), Shanghai, 200040, China

中国上海市延安西路65号上海国际贵都大饭店办公楼 405 单元

Phone: +86-21-62489820

Fax: +86-21-62489821 
(C) 2011 The Author(s). Licensee IntechOpen. This is an open access article distributed under the terms of the Creative Commons Attribution 3.0 License, which permits unrestricted use, distribution, and reproduction in any medium, provided the original work is properly cited. 